\title{
Teknik Pembibitan dan Organisme Pengganggu Bibit Durian Menoreh Kuning di Kecamatan Kalibawang, Kulon Progo
}

\author{
The Nursery Technique and Pests of Durian Menoreh Kuning in Kalibawang, Kulon Progo
}

\author{
Hermanu Triwidodo $^{1 *}$, Suryo Wiyono ${ }^{1}$, Phor Bho Ayuwati ${ }^{1}$
}

${ }^{1}$ Departemen Proteksi Tanaman, Fakultas Pertanian, Institut Pertanian Bogor

Jln. Kamper, Kampus IPB Dramaga, Bogor, Jawa Barat 16680, Indonesia

*Email korespondensi: hermanutr@apps.ipb.ac.id

Diterima: 10 Desember 2019 / Disetujui: 29 Januari 2020

\begin{abstract}
Intensive development of durian begins with effort to provide a good nurseries quality. Pests are one of many problems in providing a good nurseries quality. The objective of this research is to study the nursery technique and inventory the pests in nursery of Menoreh Kuning durian. The research were did on Kalibawang District, Kulon Progo. Interview were conducted to find out the cultivating technique in nursery of Menoreh Kuning durian. The observation of pests and diseases were carried out on seven different ages of durian nurseries (3, 12, 24, 48, 96, 6 double rootstock and 96 weeks double rootstock). Grafting using Menoreh Kuning durian for top stem with one and two rootstock were done to propagating durian. The nursery pests found were Allocaridara sp., Xyleborus sp. . Coptotermes sp., Tetranychus sp. Atractomorpha sp., and Valanga sp.. The nursery diseases found were leaf spot of Corynespora sp., leaf blight of Rhizoctonia sp., anthracnose of Colletotrichum sp., algae of Cephaleuros sp., black mildew of Meliola sp., dieback and wilt of Phytophthora sp.. These information about pests and diseases can be used to be the first thing to prevent the attack of pests on durian nurseries.
\end{abstract}

Keywords: Allocaridara sp., disease, grafting, nursery, Phytophthora sp.

\section{ABSTRAK}

Pengembangan durian secara intensif dimulai dengan upaya penyediaan bibit berkualitas. Salah satu kendala dalam penyediaan bibit durian berkualitas adalah serangan organisme pengganggu tanaman. Penelitian ini bertujuan mempelajari teknik pembibitan dan menginventarisasi keberadaan organisme pengganggu bibit durian Menoreh Kuning di Kecamatan Kalibawang, Kulon Progo. Wawancara dilakukan untuk mengetahui teknik budidaya bibit durian Menoreh Kuning. Pengamatan hama dan penyakit dilakukan pada bibit durian dengan tujuh umur berbeda (3, 12, 24, 48, 96, 6 double rootstock dan 96 minggu double rootstock). Bibit diperbanyak dengan teknik okulasi menggunakan batang atas durian Menoreh Kuning dengan satu dan dua batang bawah. Hama yang ditemukan adalah Allocaridara sp., Xyleborus sp., Coptotermes sp., Tetranychus sp., Atractomorpha $s p$., dan Valanga sp., sedangkan penyakit yang ditemukan adalah bercak daun Corynespora sp., hawar daun Rhizoctonia sp., antraknosa Colletotrichum sp., alga Cephaleuros sp., embun hitam Meliola sp., mati pucuk Phytophthora sp. dan layu Phytophthora sp.. Informasi mengenai hama dan penyakit ini dapat digunakan sebagai langkah awal dalam mencegah timbulnya OPT di pembibitan durian.

Kata kunci: Allocaridara sp., bibit, okulasi, Phytophthora sp., penyakit

\section{PENDAHULUAN}

Pengembangan durian Menoreh Kuning mulai dilakukan oleh Pemerintah Kabupaten Kulon Progo dengan upaya penyediaan bibit berkualitas. Bibit berkualitas yang dikembangkan berasal dari bibit durian milik Bapak Sugito yang telah mendapat Surat Keputusan Menteri Pertanian No 316\&317/kpts/SR120/5/2007. Pemerintah juga melakukan penanaman bibit durian Menoreh Kuning dalam kawasan 20 ha.

Pembibitan merupakan salah satu aspek penting dalam pengembangan durian. Teknik perbanyakan bibit memengaruhi keberhasilan pertumbuhan bibit. Kegagalan dalam melakukan teknik perbanyakan akan mengurangi ketersediaan bibit bagi konsumen. Perbanyakan bibit durian dapat dilakukan dengan beberapa teknik yaitu penyambungan, okulasi, cangkok dan susuan. Teknik lain dalam perbanyakan bibit durian yaitu perbanyakan generatif melalui biji namun anakan yang dihasilkan memiliki sifat yang berbeda dengan induknya dan masa panennya lama. Pembibitan durian di Indonesia masih mengalami beberapa kendala. Kendala yang dihadapi yaitu bibit durian yang beredar masih diperbanyak menggunakan biji dan bibit yang diperbanyak terserang oleh organisme pengganggu tanaman 
(OPT) sehingga bibit tidak berhasil tumbuh bahkan mati. Kondisi tersebut membuat pasokan bibit durian di pasaran berkurang dan menimbulkan kerugian bagi para penangkar (Sobir dan Martini 2014).

Menurut Lee et al. (1994), hama yang menyerang tanaman durian di Malaysia adalah kutu loncat Allocaridara malayensis (Hemiptera: Psyllidae), tungau Eutetranychus africanus (Trombidiformes: Tetranychidae), tungau Oligonychus biharensis (Trombidiformes: Tetranychidae), kutu putih Pseudococcus sp (Hemiptera: Pseudococcidae) dan tungau Tetranychus fijiensis (Trombidiformes: Tetranychidae). Penyakit yang menginfeksi tanaman durian adalah kanker bercak Phytophthora palmivora, busuk akar Pythium complectens, penyakit akar Ganoderma pseudoferreum, penyakit semai Phytophthora palmivora, mati pucuk Phytophthora palmivora, jamur upas Upasia salmonicolor, hawar daun Rhizoctonia solani, bercak daun Colletotrichum durionis, penyakit tepung Oidium nephelii dan busuk buah Phytophthora palmivora (Semangun 2007).

Teknik pembibitan dan populasi organisme pengganggu bibit durian merupakan faktor penting dalam pengembangan durian. Informasi mengenai teknik pembibitan dan organisme pengganggu bibit durian perlu diketahui untuk mencegah berkurangnya ketersediaan bibit durian di pasaran. Penelitian mengenai teknik pembibitan dan inventarisasi organisme pengganggu bibit durian terutama di Indonesia pada varietas Menoreh Kuning belum banyak dilakukan sampai saat ini. Penelitian ini bertujuan memelajari teknik pembibitan dan melakukan inventarisasi organisme pengganggu bibit durian Menoreh Kuning di Kecamatan Kalibawang, Kabupaten Kulon Progo.

\section{BAHAN DAN METODE}

Penelitian dilaksanakan bulan Februari hingga Mei 2015 pada kebun bibit durian Menoreh Kuning milik Bapak Sugito di Desa Banjaroya, Kecamatan Kalibawang, Kabupaten Kulon Progo, Daerah Istimewa Yogyakarta. Identifikasi hama dan penyakit dilaksanakan di Laboratorium Mikologi Tumbuhan, Laboratorium Biosistematika Serangga, dan Klinik Tanaman, Departemen Proteksi Tanaman, Fakultas Pertanian, Institut Pertanian Bogor.

\section{Wawancara}

Wawancara dilakukan secara langsung terhadap petani durian untuk mengetahui teknik pembibitan dan cara pengendalian hama dan penyakit. Wawancara dilakukan terhadap satu petani karena dalam satu kabupaten hanya terdapat satu petani (Bapak Sugito) yang mengembangkan bibit durian Menoreh Kuning.

\section{Pengamatan Langsung}

Pengamatan dilakukan di lahan pembibitan dengan luas $4500 \mathrm{~m}^{2}$. Tanaman bibit ditanam dalam polybag yang terdiri atas tujuh umur yaitu 3, 12, 24, 48, 96, 6 double rootstock dan 96 minggu double rootstock. Penentuan tanaman contoh dilakukan secara sistematis pada setiap petak.
Setiap petak diamati 33 baris dan setiap baris diamati tiga tanaman contoh.

Pengamatan tanaman contoh dilakukan dengan membagi tanaman menjadi tiga bagian yaitu batang, daun dan akar. Pengamatan dilakukan dengan melihat gejala serangan hama dan penyakit pada bagian-bagian tanaman tersebut. Pengamatan hama tanaman dilakukan dengan menghitung jumlah populasi. Pengamatan penyakit tanaman dilakukan dengan menghitung kejadian dan keparahan penyakit. Hama yang ditemukan kemudian dimasukkan ke dalam botol film berisi alkohol $70 \%$ dan bagian tanaman yang sakit dimasukkan ke dalam plastik. Sampel dibawa ke laboratorium untuk diamati menggunakan mikroskop stereo.

Kejadian penyakit dihitung berdasarkan rumus Cooke (2006):

$$
\mathrm{I}=\frac{n}{N} \times 100 \%
$$

Keterangan:

$$
\begin{aligned}
& \begin{array}{ll}
I & =\text { kejadian penyakit } \\
n & =\text { jumlah tanaman terinfeksi } \\
N & =\text { jumlah tanaman diamati } \\
\text { Keparahan penyakit dihitung berdasarkan rumus }
\end{array} \\
& \text { Townsend dan Heuberger (1943): } \\
& \qquad \mathrm{S}=\sum \frac{(n i . v i)}{N . V} \times 100 \% \\
& \text { Keterangan: } \\
& \begin{array}{ll}
S & =\text { keparahan penyakit } \\
n i & =\text { jumlah tanaman terserang dengan skor tertentu } \\
v i & =\text { skor infeksi penyakit } \\
N & =\text { jumlah tanaman diamati } \\
V & =\text { skor infeksi penyakit tertinggi }
\end{array}
\end{aligned}
$$

\section{Identifikasi Hama dan Penyakit}

Identifikasi hama sampai tingkat genus mengacu pada kunci identifikasi Borror et al. (1996). Identifikasi penyakit dilakukan berdasarkan gejala makroskopis dan mikroskopis. Pengamatan mikroskopis dilakukan dengan membuat preparat dari bagian tanaman yang bergejala. Identifikasi penyakit mengacu pada kunci identifikasi Barnett dan Hunter (1998).

\section{Analisis Data}

Data diolah menggunakan Microsoft Office Excel 2007 dan dilakukan analisis ragam menggunakan SAS for Windows versi 9.1 dengan uji lanjut Duncan pada taraf 5\%.

\section{HASIL DAN PEMBAHASAN}

\section{Teknik Pembibitan}

\section{Media Tanam}

Media tanam yang digunakan yaitu tanah, pupuk kompos dan sekam dengan perbandingan (4:1:1). Tanah yang digunakan mempunyai tekstur liat. Pupuk kompos merupakan campuran dari kotoran kambing atau sapi sebanyak 1 ton, dolomit 4 karung, dan tanah di sekitar perakaran bambu 4 karung. Kompos tersebut kemudian disiram EM4 dan ditutup 
dengan plastik selama tiga minggu. Menurut World Agroforestry Centre (2010), komposisi media tanam yang baik adalah campuran tanah, pupuk kandang dan sekam. Selain itu, media tanam yang baik adalah ringan, murah, mudah didapat dan subur. Penggunaan media tanam yang tepat menentukan pertumbuhan optimum bibit.

\section{Teknik Perbanyakan Bibit}

Perbanyakan bibit durian Menoreh Kuning dilakukan dengan cara okulasi. Okulasi adalah penggabungan dua bagian tanaman yang berbeda sehingga tumbuh sebagai satu tanaman setelah terjadi regenerasi jaringan pada bekas luka sambungan (WAC 2010). Teknik okulasi dilakukan dengan dua cara yaitu okulasi menggunakan satu batang bawah dan okulasi dua batang bawah.

Teknik okulasi satu batang bawah menggunakan batang atas (entres) dan batang bawah. Batang atas berasal dari klon tanaman durian Menoreh Kuning yang terdiri atas dua mata tunas untuk mengurangi kegagalan okulasi. Batang bawah berasal dari berbagai jenis durian yang telah tumbuh minimal berumur tiga bulan dan tingginya $40 \mathrm{~cm}$. Sedangkan teknik okulasi dua batang bawah (double rootstock) menggunakan hasil okulasi satu batang bawah yang telah berumur 9-12 bulan dengan entres dari varietas Menoreh Kuning. Batang bawah berasal dari varietas durian Menoreh Kuning atau varietas lain berumur minimal satu tahun. Fungsi dari dua batang bawah adalah untuk membantu percepatan pertumbuhan batang utama dan memperkokoh tanaman.

Teknik perbanyakan bibit durian yang dilakukan oleh Bapak Sugito tidak berbeda dengan teknik perbanyakan secara umumnya. Perbedaannya adalah entres yang digunakan oleh bapak Sugito berasal pohon induk tunggal (PIT) atau klon tanaman durian Menoreh Kuning. Saat ini, bibit durian yang beredar di Indonesia belum dapat dijamin keaslian varietasnya. Hal tersebut karena bibit yang dikembangkan menggunakan entres yang berasal dari pohon yang tidak bersertifikat.

\section{Hama Bibit Durian}

Hama bibit durian Menoreh Kuning yang menyerang pada bagian daun adalah kutu loncat Allocaridara sp. (Hemiptera: Psyllidae), belalang Valanga sp. (Orthoptera: Acrididae), belalang Atractomorpha sp. (Orthoptera: Pyrgomorphidae) dan tungau Tetranychus sp. (Trombidiformes: Tetranychidae). Hama bibit durian yang menyerang pada bagian batang adalah kumbang Xyleborus sp. (Coleoptera: Scolytidae) dan rayap Coptotermes sp. (Isoptera: Rhinotermitidae) (Tabel 2).

Berdasarkan hasil penelitian, Allocaridara sp. memiliki populasi dan gejala serangan paling tinggi pada semua umur bibit tanaman dibandingkan dengan hama yang lain (Gambar 1). Kondisi tersebut menunjukkan bahwa Allocaridara sp. menjadi hama yang perlu diperhatikan keberadaannya. Populasi Allocaridara sp. paling tinggi terjadi pada umur 3 dan 12 minggu. Populasi Allocaridara sp. yang tinggi pada dua umur tersebut disebabkan penyemprotan pestisida belum dilakukan. Penyemprotan pestisida oleh petani dilakukan setelah umur tanaman diatas 12 minggu. Menurut Nguyen (2003), nimfa Allocaridara sp. menghisap cairan jaringan daun muda. Serangan yang ditimbulkan mengakibatkan permukaan daun terdapat bercak kecil kuning, kering dan rontok. Populasi dan gejala serangan Xyleborus sp., Coptotermes sp., dan Tetranychus sp., memiliki nilai yang rendah. Xyleborus sp. merupakan serangga penggerek kayu yang makanannya adalah cendawan. Xyleborus sp. masuk ke batang membentuk lubang gerekan. Lubang gerek tersebut merupakan tempat bagi cendawan yang akan menjadi sumber makanan. Lubang gerek juga berfungsi sebagai pelindung terhadap predator (Sukartana 2013). Menurut Subekti (2010), Coptotermes sp. mempunyai preferensi yang tinggi terhadap tanah liat dan mengandung bahan organik tinggi. Tanah di pembibitan yang sedikit kering akibat curah hujan yang fluktuatif merupakan salah satu faktor yang menyebabkan populasi rayap rendah. Menurut Peairs dan Davidson (1961), suhu antara 27-30 ${ }^{\circ} \mathrm{C}$ menyebabkan populasi tungau rendah karena proses reproduksi terhambat.

Atractomorpha sp. dan Valanga sp. pada bibit durian juga memiliki populasi dan gejala serangan yang rendah. Cuaca yang berfluktuasi, kondisi tanah yang bertekstur liat dan perawatan terhadap bibit oleh petani memengaruhi perkembangan populasi hama tersebut. Rata-rata suhu di lokasi pembibitan adalah 27-30 ${ }^{\circ} \mathrm{C}$. Menurut Borror dan White (1970), populasi Valanga sp. dan Atractomorpha sp. rendah pada kondisi curah hujan yang fluktuatif yaitu antara 2-86 mm/hari.

Keberadaan serangga di alam dipengaruhi oleh faktor abiotik dan biotik. Faktor abiotik yang memengaruhi keberadaan serangga yaitu ketinggian, suhu, panjang hari, cahaya, curah hujan, kelembaban, angin dan perubahan iklim. Faktor biotik yang memengaruhi keberadaan serangga yaitu populasi, kompetisi dan musuh alami (Wylie dan Speight 2012).

Tabel 1. Penentuan skor infeksi penyakit

\begin{tabular}{lcc}
\hline Skor & Kategori infeksi $(\%)$ & Keterangan \\
\hline 0 & 0 & Tidak ada infeksi \\
1 & $0<\mathrm{x} \leq 25$ & Ringan \\
2 & $25<\mathrm{x} \leq 50$ & Sedang \\
3 & $50<\mathrm{x} \leq 75$ & Berat \\
4 & $>75$ & Sangat berat \\
\hline
\end{tabular}


Tabel 2. Hama dan gejala pada bibit durian Menoreh Kuning

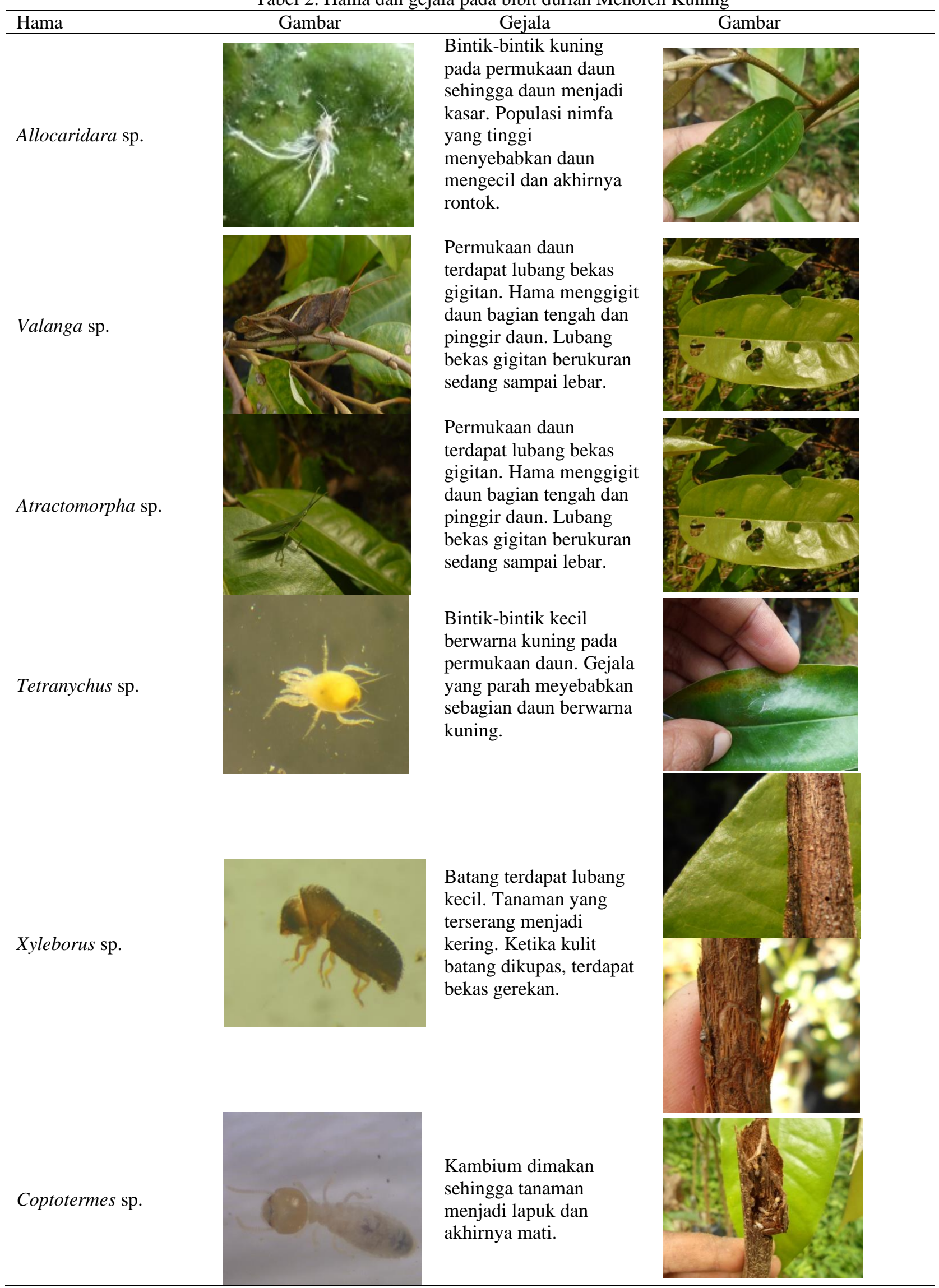




\section{Penyakit Bibit Durian}

Penyakit pada bibit durian Menoreh Kuning disebabkan oleh patogen yang berbeda-beda. Bercak daun pada durian disebabkan oleh Corynespora sp., Antraknosa disebabkan oleh Colletotrichum sp., Penyakit alga disebabkan oleh Cephaleuros sp., Embun hitam disebabkan oleh Meliola sp., Hawar daun disebabkan oleh Rhizoctonia sp. dan mati pucuk serta layu disebabkan oleh Phytophthora sp. (Tabel 3).

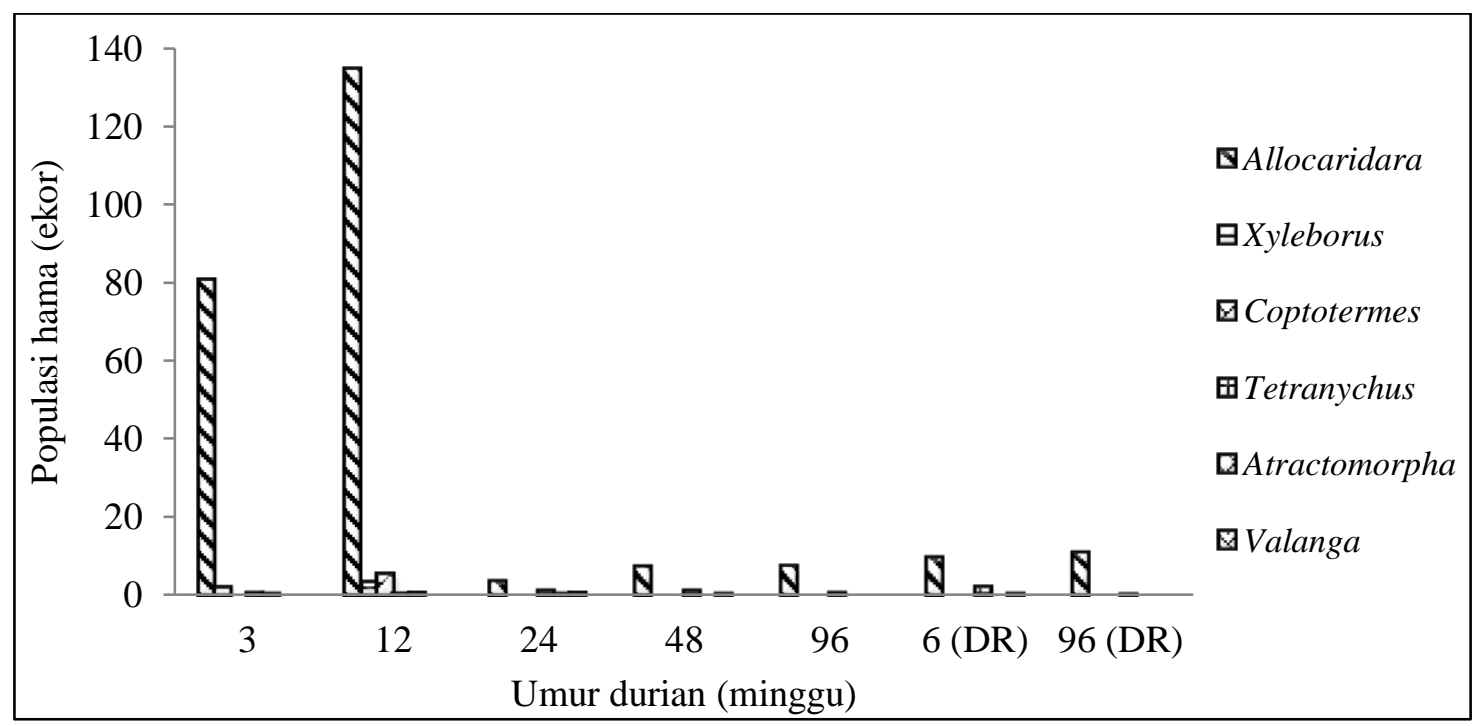

Gambar 1. Populasi hama pada setiap umur bibit durian Menoreh Kuning. DR= double rootstock

Tabel 3. Patogen dan gejala pada bibit durian Menoreh Kuning

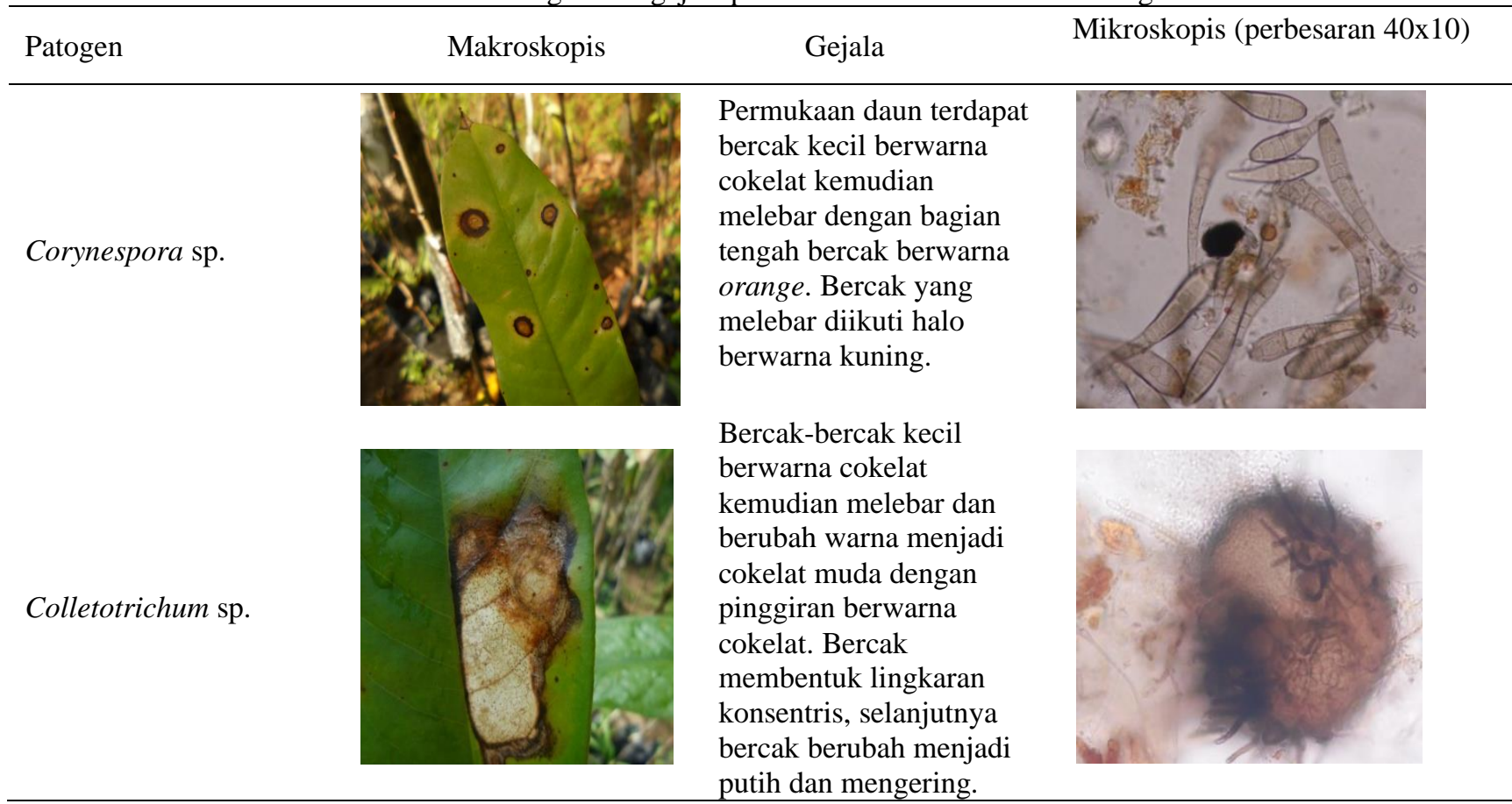


Cephaleuros sp.

Meliola sp.

Rhizoctonia sp.

Phytophthora sp.
Bercak kecil seperti karat pada permukaan daun berwarna orange. Bercak berkembang dan berubah warna menjadi hijau. Perkembangan

selanjutnya bercak akan berubah warna menjadi putih, kering dan daun berlubang.

Embun berwarna hitam pada permukaan daun yang berkumpul dalam beberapa kelompok. Embun hitam memiliki bulu sehingga permukaan daun menjadi kasar.

Bercak kebasahan pada permukaan daun kemudian melebar menyebabkan sebagian daun berwarna hijau kecokelatan, selanjutnya warna bercak berubah menjadi cokelat.
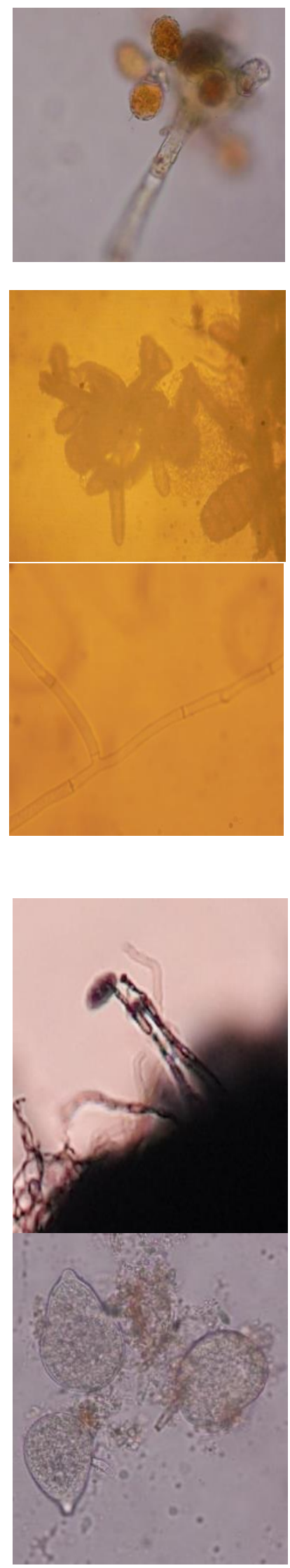

Pucuk tanaman berwarna cokelat dan lunak. Daundaun menjadi cokelat dan rontok. Akar tanaman berwarna hitam seperti busuk. Bagian batang bawah dekat akar berwarna cokelat seperti busuk.

Tanaman yang sehat tibatiba layu.

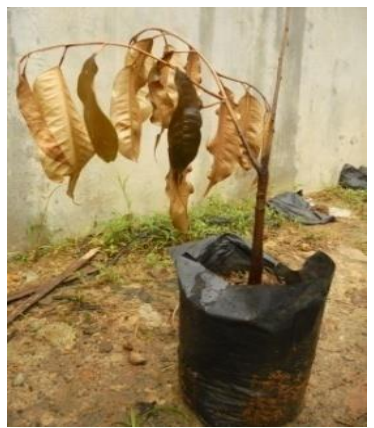


Kejadian dan keparahan penyakit bercak daun tertinggi terjadi pada umur tanaman 6 minggu double rootstock (Tabel 4 dan 5). Kejadian dan keparahan penyakit antraknosa mempunyai nilai tertinggi pada umur 3 minggu. Kondisi tersebut diduga cendawan Colletotrichum sp. lebih menyukai daun muda dan keberadaan gulma yang lebat di sekitar pembibitan durian karena belum dilakukan pemangkasan gulma. Selain itu, suhu di lokasi pembibitan berkisar 27-30 ${ }^{\circ} \mathrm{C}$. Perkembangan antraknosa paling baik terjadi pada suhu $30{ }^{\circ} \mathrm{C}$ (Semangun 2007).

Serangan Corynespora sp. yang tinggi didukung oleh curah hujan yang fluktuatif di lokasi pembibitan. Menurut Semangun (1999), Corynespora sp. dapat menginfeksi tanaman pada semua tingkat umur tanaman. Menurut Situmorang et al. (2007), kondisi curah hujan yang tinggi kurang sesuai bagi perkembangan Corynespora sp..

Kejadian dan keparahan penyakit alga tertinggi terjadi pada umur 96 minggu double rootstock. Kondisi tersebut diduga Cephaleuros sp. lebih menyukai tanaman tua. Selain itu, rendahnya kesuburan tanah, kekurangan air dan sanitasi kebun yang buruk dapat meningkatkan infeksi penyakit alga. Menurut Suwandi (2007), cendawan Cephaleuros sp. menimbulkan infeksi lebih parah pada tanaman tua dibandingkan tanaman muda.

Kejadian serta keparahan penyakit mati pucuk dan layu yang disebabkan oleh Phytophthora sp. hanya ditemukan pada bibit durian berumur 3 dan 12 minggu. Hal tersebut diduga tanaman yang masih muda rentan terinfeksi oleh patogen ini. Tingkat kejadian dan keparahan penyakit hawar daun dan embun hitam menunjukkan nilai yang rendah. Kondisi tersebut diduga dipengaruhi oleh curah hujan yang fluktuatif. Menurut Drenth dan Guest (2004), kerugian akibat infeksi Phytophthora sp. pada tanaman durian di ASEAN diperkirakan mencapai 20-25\% atau mencapai 45 triliyun rupiah. Patogen tersebut dilaporkan telah merusak $30 \%$ durian di Penang, Malaysia dan 54\% menyerang durian di Australia.

Hama dan penyakit yang menyerang tanaman durian pada fase pembibitan harus segera dikendalikan karena fase pembibitan merupakan fase yang rawan terhadap serangan OPT. Serangan OPT dapat terjadi pada semua bagian bibit durian meliputi akar, batang dan daun. Keterlambatan pengendalian dapat menyebabkan durian tumbuh abnornal. Serangan yang tinggi bahkan dapat menyebabkan kematian pada bibit durian. Bibit yang mati menyebabkan pasokan bibit di pasaran menjadi berkurang.

Tabel 4. Kejadian penyakit (\%) berdasarkan umur tanaman

\begin{tabular}{|c|c|c|c|c|c|c|c|}
\hline \multirow{2}{*}{ Penyakit } & \multicolumn{7}{|c|}{ Umur (Minggu) } \\
\hline & 3 & 12 & 24 & 48 & 96 & $6(\mathrm{DR})$ & 96 (DR) \\
\hline Bercak & $\begin{array}{c}15.00 \pm \\
3.16 \mathrm{c}\end{array}$ & $\begin{array}{l}25.00 \pm \\
2.74 \mathrm{bc}\end{array}$ & $\begin{array}{c}28.00 \pm \\
5.15 \mathrm{bc}\end{array}$ & $\begin{array}{c}14.00 \pm \\
5.75 \mathrm{c}\end{array}$ & $\begin{array}{c}17.00 \pm \\
4.06 \mathrm{c}\end{array}$ & $\begin{array}{c}50.00 \pm \\
5.48 \mathrm{a}\end{array}$ & $\begin{array}{l}37.00 \pm \\
8.75 \mathrm{ab}\end{array}$ \\
\hline Hawar & $\begin{array}{l}5.00 \pm \\
0.00 \mathrm{ab}\end{array}$ & $\begin{array}{l}2.00 \pm \\
1.22 \mathrm{~b}\end{array}$ & $\begin{array}{l}7.00 \pm \\
2.00 \mathrm{a}\end{array}$ & $\begin{array}{c}2.00 \pm \\
1.22 \mathrm{~b}\end{array}$ & $\begin{array}{l}2.00 \pm \\
1.22 \mathrm{~b}\end{array}$ & $\begin{array}{c}2.00 \pm \\
1.22 \mathrm{~b}\end{array}$ & $2.00 \pm 1.22 b$ \\
\hline Antraknosa & $\begin{array}{c}26.00 \pm \\
4.85 \mathrm{a}\end{array}$ & $\begin{array}{l}2.00 \pm \\
1.22 \mathrm{~d}\end{array}$ & $\begin{array}{l}21.00 \pm \\
7.48 \mathrm{ab}\end{array}$ & $\begin{array}{c}9.00 \pm \\
2.92 \mathrm{bcd}\end{array}$ & $\begin{array}{l}17.00 \pm \\
4.64 \mathrm{abc}\end{array}$ & $\begin{array}{l}4.00 \pm \\
1.87 \mathrm{~cd}\end{array}$ & $5.00 \pm 5.04 \mathrm{~cd}$ \\
\hline Alga & $\begin{array}{l}7.00 \pm \\
1.22 \mathrm{~cd}\end{array}$ & $\begin{array}{l}3.00 \pm \\
2.00 \mathrm{~d}\end{array}$ & $\begin{array}{l}15.00 \pm \\
3.16 \mathrm{bcd}\end{array}$ & $\begin{array}{l}9.00 \pm \\
1.87 \mathrm{~cd}\end{array}$ & $\begin{array}{l}24.00 \pm \\
8.72 \mathrm{abc}\end{array}$ & $\begin{array}{c}42.00 \pm \\
7.52 \mathrm{a}\end{array}$ & $\begin{array}{c}33.00 \pm \\
10.2 \mathrm{ab}\end{array}$ \\
\hline Embun hitam & $\begin{array}{l}4.00 \pm \\
1.87 \mathrm{bc}\end{array}$ & $\begin{array}{l}1.00 \pm \\
1.00 \mathrm{bc}\end{array}$ & $\begin{array}{l}0.00 \pm \\
0.00 \mathrm{c}\end{array}$ & $\begin{array}{l}5.00 \pm \\
2.24 \mathrm{bc}\end{array}$ & $\begin{array}{l}7.00 \pm \\
1.22 \mathrm{~b}\end{array}$ & $\begin{array}{l}4.00 \pm \\
2.92 \mathrm{bc}\end{array}$ & $13.00 \pm 3.00 \mathrm{a}$ \\
\hline $\begin{array}{l}\text { Mati pucuk dan } \\
\text { Layu }\end{array}$ & $\begin{array}{l}2.00 \pm \\
1.22 \mathrm{ab}\end{array}$ & $\begin{array}{l}3.00 \pm \\
2.00 \mathrm{a}\end{array}$ & $\begin{array}{l}0.00 \pm \\
0.00 \mathrm{~b}\end{array}$ & $\begin{array}{c}0.00 \pm \\
0.00 b\end{array}$ & $\begin{array}{l}0.00 \pm \\
0.00 \mathrm{~b}\end{array}$ & $\begin{array}{c}0.00 \pm \\
0.00 \mathrm{~b}\end{array}$ & $0.00 \pm 0.00 b$ \\
\hline
\end{tabular}

Keterangan: Angka pada baris yang sama diikuti huruf yang sama menunjukkan tidak berbeda nyata pada taraf $\alpha=5 \%$ berdasarkan uji selang ganda Duncan

Tabel 5. Keparahan penyakit (\%) berdasarkan umur tanaman

\begin{tabular}{|c|c|c|c|c|c|c|c|}
\hline \multirow{2}{*}{ Penyakit } & \multicolumn{7}{|c|}{ Umur (Minggu) } \\
\hline & 3 & 12 & 24 & 48 & 96 & $6(\mathrm{DR})$ & 96 (DR) \\
\hline \multirow{2}{*}{ Bercak } & $3.75 \pm$ & $6.75 \pm$ & $7.25 \pm$ & $3.50 \pm$ & $4.75 \pm$ & $13.00 \pm$ & $11.50 \pm$ \\
\hline & $0.79 \mathrm{c}$ & $0.64 b c$ & $1.39 \mathrm{bc}$ & $1.39 \mathrm{c}$ & $1.45 \mathrm{c}$ & $1.16 \mathrm{a}$ & $3.07 \mathrm{ab}$ \\
\hline \multirow{2}{*}{ Hawar } & $1.75 \pm$ & $0.50 \pm$ & $2.25 \pm$ & $0.50 \pm$ & $0.75 \pm$ & $0.50 \pm$ & $0.50 \pm$ \\
\hline & $0.31 \mathrm{ab}$ & $0.31 \mathrm{c}$ & $0.47 \mathrm{a}$ & $0.31 \mathrm{c}$ & $0.50 \mathrm{bc}$ & $0.31 \mathrm{c}$ & $0.31 \mathrm{c}$ \\
\hline \multirow{2}{*}{ Antraknosa } & $10.00 \pm$ & $1.25 \pm$ & $6.25 \pm$ & $3.00 \pm$ & $7.25 \pm$ & $1.25 \pm$ & $1.25 \pm$ \\
\hline & $1.94 \mathrm{a}$ & $0.97 \mathrm{c}$ & $1.58 \mathrm{ab}$ & $1.16 b c$ & $2.03 \mathrm{ab}$ & $0.53 \mathrm{c}$ & $1.25 \mathrm{c}$ \\
\hline \multirow{2}{*}{ Alga } & $1.75 \pm$ & $0.75 \pm$ & $3.75 \pm$ & $2.25 \pm$ & $6.50 \pm$ & $10.75 \pm$ & $11.5 \pm$ \\
\hline & $0.31 b c$ & $0.50 \mathrm{c}$ & $0.79 b c$ & $0.47 b c$ & $2.28 \mathrm{ab}$ & $2.08 \mathrm{a}$ & $3.12 \mathrm{a}$ \\
\hline \multirow{2}{*}{ Embun hitam } & $1.50 \pm$ & $0.25 \pm$ & $0.00 \pm$ & $2.75 \pm$ & $3.50 \pm$ & $1.00 \pm$ & $4.00 \pm$ \\
\hline & $0.73 \mathrm{bcd}$ & $0.25 \mathrm{~d}$ & $0.00 \mathrm{~d}$ & $1.39 \mathrm{abc}$ & $0.47 \mathrm{ab}$ & $0.73 \mathrm{~cd}$ & $0.61 \mathrm{a}$ \\
\hline Mati pucuk dan & $0.75 \pm$ & $1.00 \pm$ & $0.00 \pm$ & $0.00 \pm$ & $0.00 \pm$ & $0.00 \pm$ & $0.00 \pm$ \\
\hline Layu & $0.5 \mathrm{ab}$ & $0.61 \mathrm{a}$ & $0.00 \mathrm{~b}$ & $0.00 \mathrm{~b}$ & $0.00 \mathrm{~b}$ & $0.00 \mathrm{~b}$ & $0.00 \mathrm{~b}$ \\
\hline
\end{tabular}

Keterangan: Angka pada baris yang sama diikuti huruf yang sama menunjukkan tidak berbeda nyata pada taraf $\alpha=5 \%$ berdasarkan uji selang ganda Duncan 


\section{KESIMPULAN}

Teknik perbanyakan yang diterapkan yaitu okulasi menggunakan batang atas durian Menoreh Kuning dengan satu (rootstock) dan dua batang bawah (double rootstock). Hama yang menyerang bibit durian adalah Allocaridara sp., Valanga sp., Atractomorpha sp., Tetranychus sp., Xyleborus sp. dan Coptotermes sp.. Penyakit yang menginfeksi bibit durian yaitu bercak daun Corynespora sp., hawar daun Rhizoctonia sp., antraknosa Colletotrichum sp., alga Cephaleuros sp., embun hitam Meliola sp., mati pucuk dan layu oleh Phytophthora sp.

\section{UCAPAN TERIMA KASIH}

Penelitian ini dapat berjalan dengan lancar karena bantuan teknis dan arahan dari Bapak Sugito sebagai pemilik kebun perbanyakan bibit durian Menoreh Kuning.

\section{DAFTAR PUSTAKA}

Barnett, H.L., \& Hunter B.B. (1998). Illustrated Genera of Imperfect Fungi. Ed ke-4. Minnesota: Aps Press.

Borror, D.J., Triplehorn C.A., Johnson, N.F.. (1996). Pengenalan Pelajaran Serangga. Ed. ke-6. P. Soetiyono, penerjemah. Yogyakarta: Gadjah Mada University Press. Terjemahan dari: An Introduction to The Studies of Insects.

Borror, R.E.W. (1970). A Field Guide to The Insects. Boston: Houghton Mifflin.

Cooke, B.M. (2006). Disease Assessment and Yield Loss. In Cooke, B.M., D.G. Jones, B. Kaye (Eds.). The Epidemiology of Plant Diseases, 2nd Ed. Springer, Dordrecht.

Drent, A., \& Guest, D.I.. (2004). Diversity and Management of Phytophthora in Southeast Asia. Canberra: ACIAR Monograph.

Lee, B.S., Kosittrakun, M., Vichitrananda, S. (1994). Chapter 7: Pathology and Disease Control. In S. Nanthachai $(E d$.). Durian: Fruit Development, Post-harvest Physiology, Handling and Marketing in ASEAN. ASEAN Food Handling Bureau. Kuala Lumpur.

Nguyen, V.H. (2003). Serangga pertanian bagian B: hama serangga tanaman utama. Delta Mekong (VN):
Universitas Can Tho. http://thienho.com/w1/tailieu/pdf/Kho-giao-trinh/DHCT-con-trung-nongnghiep-nv-huynh-lt-sen.pdf [27 Mei 2003].

Peairs, D. (1961). Insect Pest of Farm Garden and Orchard. London: John Wiley and Sons.

Semangun, H. (1999). Penyakit-penyakit Tanaman Perkebunan di Indonesia. Yogyakarta: Gadjah Mada University Press.

Semangun, H. (2007). Penyakit-penyakit Tanaman Hortikultura di Indonesia. Ed ke-2. Yogyakarta: UGM Press.

Situmorang, A., Sinaga, M.S., Suseno, R., Hidayat, S.H., Siswanto, \& Darussamin, A. (2007). Sebaran penyakit gugur daun Corynespora di sentra perkebunan karet Indonesia. Jurnal Penelitian Karet. 25(1):76-82.

Sobir, E.M. (2014). Pedoman Budi Daya Durian dan Rambutan di Kebun Campur. Bogor: World Agroforestry Centre (ICRAF) Southeast Asia Regional Program.

Subekti, N. (2010). Karakteristik populasi rayap tanah Coptotermes spp (Blattodea: Rhinotermitidae) dan dampak serangannya. http://download.portalgaruda.org/article.php?article= $\underline{136078 \& \mathrm{val}=5659}$ [26 Mei 2010].

Sukartana, P. (2013). Arti Penting Pemahaman Perilaku Serangga Perusak Kayu untuk Pengendaliannya yang Lebih Ramah Lingkungan. di dalam: Sudradjat et al. (Eds.). Orasi Ilmiah Ahli Peneliti Utama (APU). Himpunan Bunga Rampai. Bogor 3 Desember 2013.

Suwandi. (2007). Peledakan penyakit karat merah alga pada tanaman gambir. (Uncaria gambi) di Babat Tomat, Sumatera Selatan. Pet Tropical Journal. 1(1).

Townsend, G.R., J.V. Heuberger. (1943). Methods for estimating losses caused by diseases in fungicide expreminent. Plant Disease Report, 24:340-343.

[WAC] World Agroforestry Centre. (2010). Teknik Pembibitan dan Perbanyakan Vegetatif Tanaman Buah. Bogor: WAC.

Wylie, F.R., M.R. Speight. (2012). Insect Pest in Tropical Forestry. Ed ke-2. London: CABI. 